\title{
Effect of Lysolecithin Supplementation to Low-energy Broiler Diets on Performance and Subsequent Cost-benefit Analysis
}

\author{
Abdallah A. Ghazalah ${ }^{1}$, Mamdouh O. Abd-Elsamee ${ }^{1}$, Moataz M. Ibrahim²,1, David Gonzalez-Sanchez ${ }^{3 *}$, \\ Alexandra L. Wealleans ${ }^{3}$, and Mohamed Abdelkader ${ }^{3}$ \\ ${ }^{I}$ Department of Animal Production, Faculty of Agriculture, Cairo University, Giza, 12613, Egypt \\ ${ }^{2}$ R\&D Department, Feed Division, Cairo Poultry Group, Americana, Giza, 12511, Egypt \\ ${ }^{3}$ Kemin Europa N.V., Herentals, 2200, Belgium \\ *Corresponding author's email: David.gonzalezsanchez@kemin.com; ORCID: 0000-0002-4550-5147
}

Received: 30 Mar. 2021

Accepted: 17 May 2021

\begin{abstract}
The use of lysolecithin as an emulsifier in the diet of chickens could improve the growth performance. Its commercial application in broiler diets containing medium to high levels of added oil is increasingly adopted. However, few studies have assessed the impact of lysolecithin supplementation in diets formulated with no added oil. Therefore, this study aimed to compare two feeding diets based on commercial low-energy diets with no added oil, with or without a nutrient absorption enhancer based on lysolecithin (LEX). The performance was recorded on days 7, 14, 21, and 28. The net benefit per chicken of LEX supplementation was determined across a range of cost and performance scenarios. At slaughter, average body weight and feed conversion ratio were significantly improved in LEX-treated chickens, compared to non-treated chickens. The net benefit per chicken of LEX supplementation was $€ 0.023$ under representative market conditions and remained profitable under all considered scenarios. In conclusion, the application of absorption enhancers based on lysolecithin could improve the performance and profitability of broiler production, even in low energy-dense diets formulated with no added oil.
\end{abstract}

Keywords: Broilers, Cost-Benefit, Economics, Lysolecithin, Performance

\section{INTRODUCTION}

Broiler chickens with high genetic potential for growth require diets with high energy and amino acid content (Johnson et al., 2020b). Formulating broiler diets to meet those high nutrient requirements leads to an increased feed efficiency as well as feed cost. Controlling feed cost has become a difficult task in a market context of price volatility for energetic and proteinaceous raw materials. As the provision of energy generally accounts for a high proportion of total diet costs, optimizing the availability of dietary energy to broilers is essential for cost-effective production. The digestion of lipids is a complex process, with the sequential steps of emulsification, hydrolysis, and absorption, which is often less studied than those of other nutrients (Ravindran et al., 2016). Although total tract digestibility of lipids is high (Tancharoenrat et al., 2013), incomplete absorption can lead to reduced performance, disturbances to the gut microbiota (Pan and Yu, 2014), and an increase in footpad lesions (Zampiga et al., 2016).
Availability and absorption of fats and oils are determined by multiple factors intrinsic to each oil source: fatty acid chain length (Wiseman et al., 1991), fatty acid position on the triglyceride (Smink et al., 2008), level of saturation (Sanz et al., 2000), as well as the presence of energy diluting compounds, such as moisture and impurities (Wealleans et al., 2021).

Although the addition of exogenous bile salts has been shown to improve fat digestion in young chicks under research conditions (Maisonnier et al., 2003), their use in commercial broiler formulations is impractical. Therefore, attention is focused on compounds that can aid poultry at each digestive step, such as lysolecithin. Previous studies have shown that lysolecithin is effective in improving energy availability directly (Boontiam et al., 2019; Wealleans et al., 2020a; Haetinger et al., 2021) from both added fat and cereal ingredients. By releasing other nutrients from the fat matrix, improvements are also seen in protein (Papadopoulos et al., 2018; Haetinger et al., 
2021) and amino acid utilization (Wealleans et al., 2019) leading to better performance (Wealleans et al., 2020a,b; Haetinger et al., 2021) and carcass quality (Chen et al., 2019) in broilers fed with both high and low energy density diets. The ability of pure lysolecithin to improve energy digestion and absorption can be further improved by the addition of synthetic emulsifiers and monoglycerides (Jansen, 2015).

Commercially, many companies formulate diets with energy levels below the official breed recommendations using low-energy-density ingredients and limited added oil. As traditionally the mode of action of nutrient absorption enhancers based on lysolecithin was linked directly to the emulsification of fats and oils. To our knowledge, there are no published results of the efficacy of lysolecithin under such dietary conditions to date. Therefore, this study aimed to investigate the ability of lysolecithin to improve the growth and profitability of broilers fed low-energy diets formulated without added oil.

\section{MATERIALS AND METHODS}

\section{Ethical approval}

All experimental procedures were in line with commercial practices and approved by the Institutional Animal Care and Use Committees of the Faculty of Science, Cairo University, Egypt (CUIIF2420) and were compliant with all local animal welfare legislation.

\section{Study area}

The present trial was conducted at the Broiler Research Unit of Cairo Poultry Company, El-Saf, Giza, Egypt.

\section{Study design}

The duration of the study was 28 days. At the start of the study, 300 one-day-old Arbor Acres broilers (46.19 \pm $3.77 \mathrm{~g}$ at hatch) were obtained from the commercial hatchery of Cairo Poultry Company (Nobaria city, Egypt), and at arrival at the trial site, they were randomly allocated to two dietary treatments with 6 replicates of 25 mixed-sex broilers each. The investigated groups included a commercial control diet formulated to low energy content meet all nutrient requirements, as shown in Table 1 (Control), and the same low-energy diet supplemented with a nutrient absorption enhancer based on lysolecithin (LEX) at $250 \mathrm{~g} / \mathrm{t}$ (experimental group). The nutrient absorption enhancer used in the current study was
LYSOFORTE $^{\circledR}$ EXTEND (Kemin Europa NV, Herentals, Belgium).

Table 1. Ingredients, nutrient composition, and costs of the basal experimental diets ${ }^{1}$

\begin{tabular}{|c|c|c|c|}
\hline Ingredient composition $(\mathrm{g} / \mathrm{kg})$ & $\begin{array}{c}\text { Days } \\
0-10\end{array}$ & $\begin{array}{c}\text { Days } \\
11-21 \\
\end{array}$ & $\begin{array}{c}\text { Days } \\
22-28 \\
\end{array}$ \\
\hline Corn & 545.7 & 567.0 & 619.6 \\
\hline Soybean meal, $47 \%$ & 359.7 & 330.0 & 291.1 \\
\hline Full fat soybeans & 53.3 & 77.0 & 70.0 \\
\hline Limestone & 12.2 & 11.2 & 9.4 \\
\hline Corn gluten meal, $60 \%$ & 10.0 & - & - \\
\hline Monocalcium phospate & 7.1 & 4.6 & 3.1 \\
\hline Sodium chloride & 2.5 & 2.5 & 2.5 \\
\hline L-Lysine $\mathrm{HCl}$ & 3.0 & 1.9 & - \\
\hline DL Methionine & 2.6 & 2.2 & 1.8 \\
\hline L-Threonine & 1.7 & 1.4 & 0.3 \\
\hline Vitamin and Mineral Premix ${ }^{2}$ & 2.0 & 2.0 & 2.0 \\
\hline Cost per tonne $\left(\epsilon^{3}\right)$ & 275.9 & 267.6 & 256.00 \\
\hline \multicolumn{4}{|l|}{ Calculated composition (\%) } \\
\hline Dry Matter & 88.06 & 87.97 & 87.84 \\
\hline Metabolizable Energy, $\mathrm{kcal} / \mathrm{kg}$ & 2900 & 2950 & 3000 \\
\hline Metabolizable Energy, MJ/kg & 12.14 & 12.35 & 12.56 \\
\hline Crude Protein & 24.00 & 22.92 & 21.00 \\
\hline Crude Fat & 4.12 & 4.59 & 3.60 \\
\hline Crude Fibre & 2.77 & 2.86 & 2.56 \\
\hline Lysine & 1.43 & 1.29 & 1.13 \\
\hline Methionine & 0.58 & 0.52 & 0.50 \\
\hline Methionine + Cysteine & 0.88 & 0.82 & 0.84 \\
\hline Threonine & 0.94 & 0.88 & 0.84 \\
\hline Arginine & 1.42 & 1.37 & 1.38 \\
\hline Tryptophan & 0.25 & 0.25 & 0.25 \\
\hline Calcium & 0.96 & 0.88 & 0.80 \\
\hline Available phosphorus & 0.48 & 0.43 & 0.40 \\
\hline Sodium & 0.16 & 0.16 & 0.16 \\
\hline Chlorine & 0.23 & 0.21 & 0.18 \\
\hline \multicolumn{4}{|l|}{ Analyzed composition $(\%)$} \\
\hline Dry Matter & 88.01 & 88.75 & 87.65 \\
\hline Crude protein & 23.91 & 23.01 & 20.89 \\
\hline Crude fibre & 2.58 & 2.70 & 2.59 \\
\hline Crude fat & 4.00 & 4.56 & 3.91 \\
\hline Calcium & 0.961 & 0.884 & 0.812 \\
\hline
\end{tabular}

${ }^{1}$ To create the experimental treatment (LEX), LYSOFORTE ${ }^{\circledast}$ EXTEND (a nutrient absorption enhancer based on lysolecithin, synthetic emulsifiers, and monoglycerides) was added on top at $250 \mathrm{~g} / \mathrm{t}$ at the expense of corn. ${ }^{2}$ Provided per kilogram of diet: Vitamin A (E 672): 10,000 IU, Vitamin D3 (E 671): 3,500 IU, Vitamin E ( $\alpha$-tocopherol): 20 IU, Vitamin K3: $2.5 \mathrm{mg}$, Vitamin B1: $2 \mathrm{mg}$, Vitamin B2: $6.5 \mathrm{mg}$, Vitamin B6: $3 \mathrm{mg}$, Vitamin B12: $16 \mu \mathrm{g}$, Nicotinic acid: $45 \mathrm{mg}$, Pantothenic acid: $12 \mathrm{mg}$, Choline chloride: $270 \mathrm{mg}, \mathrm{Cu}$ (CuSO4.5H2O): $8 \mathrm{mg}$, Fe (FeSO4.H2O): $33 \mathrm{mg}$, I (IK): $1.1 \mathrm{mg}$, Mn (MnSO4.H2O): 90 $\mathrm{mg}$, Se (Na2SeO3): $0.34 \mathrm{mg}, \mathrm{Zn}(\mathrm{ZnO}): 75 \mathrm{mg}$, Protease: $4000 \mathrm{U}$, Xylanase: $2000 \mathrm{U}$, and Amylase: $200 \mathrm{U} .{ }^{3}$ Cost per tonne of finished feed based on ingredient costs at Quarter 2, 2020. 
Chickens received all standard hatchery vaccinations against Newcastle disease, infectious bronchitis, infectious bursal disease, and avian influenza H5N1 at the hatchery, and no concomitant drug therapy was used during the study. Pens were of equal size of $2 \mathrm{~m}^{2}$ with wood shavings as litter material and pen allocation per treatment was randomized. The temperature and ventilation of the building were monitored daily and maintained optimum for the age of the chickens according to the breed recommendations. A regular lighting program (0-3 days 24 hours/light, 4-7 days 23 hours/light, and 8-28 days 20 hours/light) was provided by fluorescent bulbs placed above the pens.

\section{Experimental diets}

Diets were fed in three phases according to the standard feeding program of Cairo Poultry Company, with a pre-starter diet from hatching to day 10 , a starter diet from days 11-21, and a grower diet from days 22-28. Diets were formulated to low-energy content compared to Arbor Acres broiler nutrition specifications with around 50 $\mathrm{kcal} / \mathrm{kg}$ Apparent Metabolizable Energy lower than normal commercial standards for all feeding phases and according to the nutrient composition of ingredients of Cairo Poultry Company, Egypt. All diets were produced according to commercial practices and fed as pellets. The ingredient and chemical composition of the control diet is shown in Table 1 . The feed and water were provided ad libitum throughout the study.

\section{Growth performance assessment}

Individual weights for all chickens were taken at study initiation, and days 7, 14, 21, and 28. Individual weights were averaged so as to provide pen-level data. Feed consumption and Feed Conversion Ratio (FCR) were calculated weekly, and pens were monitored daily for mortality. On day 28 , all chickens were slaughtered and final average body weights, feed intakes, and FCR were calculated.

\section{Statistical analysis}

The pen/replicate was considered the experimental unit. No outlier data was identified or excluded from the dataset. Performance data were analyzed using JMP 15 (SAS Institute, Cary, NC), with the effect of treatment as the main factor. Differences were considered significant at $\mathrm{p}<0.05$.

\section{Cost-benefit analysis}

The net benefit was estimated from the farm gate price received per live weight $\mathrm{kg}$ of chicken. The mean price was estimated to be $€ 0.90$ per $\mathrm{kg}$ as a representative market price in Quarter 2, 2020. The model assumed that there was no difference in Body Weight Gain (BWG) between treatment groups.

Estimated diet prices for each phase are shown in Table 1. Ingredient prices were taken from the actual costs of the ingredients at the time of the study (Quarter 2, 2020). The average control diet cost for the whole study was calculated from the different phase diet costs on a proportional feed consumption basis. The added cost of the nutrient absorption enhancer (LEX) supplementation was considered on top of the control diet cost. Margin over feed cost was calculated for every treatment and the difference between treatments was expressed as net benefit per chicken.

A sensitivity analysis was then conducted on the net benefit per chicken arising from LEX supplementation against the control to investigate the effect of changes in feed cost and FCR response to treatment, as mentioned by Wealleans et al. (2018). The sensitivity analysis assumed a range of feed costs between 225 and $325 € /$ ton and changes in FCR of 0.0 .5 and 1.5 times that seen in the current study, compared to the control group.

\section{RESULTS}

Table 2 presents the effect of supplementing chickens fed a low-energy diet with a nutrient absorption enhancer based on lysolecithin on growth performance across the 28-day rearing period. There was no significant difference in chicken weight between groups at the beginning of the study, with chicks weighing an average of $46.19 \mathrm{~g}$ at hatch day. By day 7, however, there was a significant difference in average body weight between treatments, chickens receiving LEX were $3.5 \%$ heavier than those fed with the control diet $(p<0.05)$. Significant differences in body weight remained throughout the trial with $5.2 \%, 7.5 \%$, and $7.8 \%$ improvements for LEX-treated chickens on days 14 , 21 , and 28 , respectively $(\mathrm{p}<0.05)$. In each growing phase, chickens from the experimental group consumed more feed, compared to the chickens from the control. This difference was statistically significant during 14-21 days $(\mathrm{p}<0.05)$. From hatch to slaughter, the difference in feed intake between treatment groups was also statistically significant, with LEX supplemented chickens consuming $71 \mathrm{~g}$ or $3.3 \%$ more than control chickens $(\mathrm{p}<0.05)$. Regarding FCR, there was a tendency for reduced FCR between treatments from hatching to day 7, with significantly reduced FCR in days 7-14 ( $<<0.05)$, and 14$21(\mathrm{p}<0.05)$. The proportional difference widened as 
chickens grew older $(-2.5 \%$ for $0-7 \mathrm{~d},-3.4 \%$ for $7-14 \mathrm{~d}$, $3.2 \%$ for $14-21 \mathrm{~d},-7.3 \%$ for $21-28 \mathrm{~d}$ ). Overall, from hatch to slaughter, LEX supplementation resulted in a significant reduction of $4.6 \%$ in FCR ( $\mathrm{p}<0.05$ ), compared to control. The cost-benefit analysis resulted in net savings of $€ 0.023$ per chicken ( $€ 23$ per 1000 chickens) because of improved FRC following LEX supplementation under representative prices for Quarter 2, 2020 (Table 3). Table 4 shows the effect of varying cost and performance scenarios on the net saving value of LEX supplementation, according to the same methodology used for Table 3. As the basal control diet cost increases, the savings due to improved feed efficiency proportionally increase. The LEX treatment remained profitable under all considered conditions.

Table 2. The effect of dietary supplementation of a nutrient absorption enhancer based on lysolecithins to lowenergy diets on productive performance of broiler chickens measured at different growth stages

\begin{tabular}{|c|c|c|c|c|}
\hline & Control & LEX & SEM & $P$ value \\
\hline Body weight at hatch & 45.89 & 46.49 & 0.138 & 0.0573 \\
\hline \multicolumn{5}{|l|}{ 0-7 days } \\
\hline BW (day 7) & 213.07 & 220.50 & 1.273 & 0.0170 \\
\hline BWG (g) & 167.17 & 174.01 & 1.253 & 0.0230 \\
\hline FI $(g)$ & 166.77 & 169.23 & 1.133 & 0.3045 \\
\hline FCR & 0.998 & 0.973 & 0.009 & 0.0806 \\
\hline \multicolumn{5}{|l|}{ 7-14 days } \\
\hline BW (day 14) & 565.11 & 594.73 & 2.424 & 0.0002 \\
\hline BWG (g) & 352.05 & 374.23 & 2.575 & 0.0020 \\
\hline $\mathrm{FI}(\mathrm{g})$ & 440.11 & 451.60 & 3.474 & 0.1371 \\
\hline FCR & 1.252 & 1.209 & 0.007 & 0.0150 \\
\hline \multicolumn{5}{|l|}{ 14-21 days } \\
\hline BW (day 21) & 1002.17 & 1077.03 & 6.777 & 0.0004 \\
\hline BWG (g) & 437.05 & 482.30 & 6.138 & 0.0050 \\
\hline FI (g) & 655.02 & 694.80 & 7.153 & 0.0210 \\
\hline FCR & 1.502 & 1.444 & 0.010 & 0.0170 \\
\hline FCR (0-21 days) & 1.321 & 1.278 & 0.0049 & 0.0020 \\
\hline \multicolumn{5}{|l|}{ 21-28 days } \\
\hline BW (day 28) & 1551.77 & 1673.40 & 17.637 & 0.0070 \\
\hline BWG (g) & 549.60 & 596.37 & 15.123 & 0.1564 \\
\hline FI (g) & 909.47 & 926.67 & 13.087 & 0.5275 \\
\hline FCR & 1.675 & 1.553 & 0.038 & 0.1414 \\
\hline \multicolumn{5}{|l|}{ 0-28 days } \\
\hline BWG (g) & 1505.87 & 1626.91 & 17.594 & 0.0070 \\
\hline FI (g) & 2171.37 & 2242.30 & 14.776 & 0.0400 \\
\hline FCR & 1.446 & 1.379 & 0.012 & 0.0190 \\
\hline Mortality (\%) & 0 & 0 & - & - \\
\hline
\end{tabular}

LEX: LYSOFORTE ${ }^{\circledR}$ EXTEND: A nutrient absorption enhancer based on lysolecithin, synthetic emulsifiers, and monoglycerides. SEM: Standard error of mean (overall), $\mathrm{n}=6$ replicates per treatment $(25$ chickens per replicate). BW: Body weight, BWG: Body weight gain, FI: Feed intake, FCR: Feed conversion ratio
Table 3. The effect of dietary supplementation of a nutrient absorption enhancer based on lysolecithins to lowenergy diets on the profitability of broiler chicken production

\begin{tabular}{|c|c|c|}
\hline Items & Control & LEX \\
\hline $\operatorname{ADWG}(\mathrm{g})^{1}$ & 53.76 & 53.76 \\
\hline Bird price/kg liveweight $(€)$ & 0.90 & 0.90 \\
\hline Value of chicken at the sale $(€)$ & 1.40 & 1.40 \\
\hline FCR & 1.446 & 1.379 \\
\hline FCR improvement (\%) & - & 4.65 \\
\hline Feed Intake (kg) & 2.18 & 2.08 \\
\hline Feed cost $(€ / t)^{2}$ & 263.5 & 265.5 \\
\hline Feed cost $(€ /$ bird $)$ & 0.57 & 0.55 \\
\hline Margin Over Feed Cost (€/bird) & 0.823 & 0.846 \\
\hline Net benefit/bird $(€)$ & - & 0.023 \\
\hline Net benefit/1000 birds $(€)$ & - & 23 \\
\hline \multicolumn{3}{|c|}{$\begin{array}{l}\text { LEX: LYSOFORTE }{ }^{\circledR} \text { EXTEND (a nutrient absorption enhancer based on } \\
\text { lysolecithin, synthetic emulsifiers, and monoglycerides). ADWG: } \\
\text { Average daily weight gain, FCR: Feed conversion ratio. }{ }^{1} \text { Assuming } \\
\text { chickens grown to the same weights, as per Wealleans et al. (2018). }{ }^{2} \text { The } \\
\text { average control diet cost for the whole study was calculated from the } \\
\text { different phase diet costs on a proportional feed consumption basis. The } \\
\text { LEX supplementation cost was added to the control diet cost. }\end{array}$} \\
\hline
\end{tabular}

Table 4. The effect of dietary supplementation of a nutrient absorption enhancer based on lysolecithins to lowenergy diets on the profitability of broiler production (net benefit per 1000 chickens) under varying feed cost and performance scenarios

\begin{tabular}{|c|c|c|c|c|c|}
\hline \multirow{2}{*}{ Items } & \multicolumn{5}{|c|}{ Price of control feed per tonne ${ }^{2}, €$} \\
\hline & 225 & 250 & 275 & 300 & 325 \\
\hline $0.5 \times$ FCR changes seen ${ }^{1}$ & 7.1 & 8.3 & 9.6 & 10.8 & 12.1 \\
\hline FCR changes as seen & 18.6 & 21.2 & 23.7 & 26.2 & 28.8 \\
\hline $1.5 \times$ FCR changes seen ${ }^{1}$ & 30.1 & 33.9 & 37.7 & 41.5 & 45.3 \\
\hline
\end{tabular}

${ }^{1}$ vs. commercial control low-energy diet; ${ }^{2}$ per tonne of finished feed including the cost of additive; FCR: Feed conversion ratio.

\section{DISCUSSION}

In previous studies, the addition of lysolecithin to diets with low-energy content has been shown to increase the growth performance of broiler chickens (Papadopoulos et al., 2018; Boontiam et al., 2019). The improvement in growth rate and efficiency was already apparent on day 7 with the body weight of LEX-treated chickens 3\% higher than that of chickens fed with the control diet. Although feed intake is very low in young chicks, and subsequently the intake of lysolecithin is also very low, the improvement in fat digestion following lysolecithin supplementation can be substantial (Wealleans et al., 2020a). The reason is that young chicks are unable to fully 
digest fat due to their limiting production of bile salts (Maisonnier et al., 2003; Maiorka et al., 2004). As the chicks grow older, the beneficial effect of the nutrient absorption enhancer increased, leading to an $8 \%$ increase in body weight of LEX-treated chickens at slaughter, compared to that of control chickens. The FCR across the whole trial was also substantially and significantly improved by LEX supplementation.

Previous studies have also reported increases in growth rate following lysolecithin supplementation although the proportional increase has often been smaller than that observed in the current study. Papadopoulos et al. (2018) reported $2 \%$ and $4 \%$ growth improvement to slaughter with 300 and $500 \mathrm{~g} / \mathrm{t}$ of a nutrient absorption enhancer based on lysolecithin while Khonyoung et al. (2015) estimated 1-3\% improvements with variation by basal fat source. The extent of the growth performance improvement following the supplementation of lysolecithin may be linked to the underlying performance potential of the diet. Chen et al. (2019) also reported body weight gain (BWG) improvements of approximately $2 \%$ following the supplementation of a nutrient absorption enhancer based on lysolecithin at $250 \mathrm{~g} / \mathrm{t}$ in normal energy diets, the same level of supplementation in reduced energy diets $(-100 \mathrm{kcal})$ resulted in a $6.7 \%$ improvement in BWG. In line with commercial practice, the diets used in the current study were below the Arbor Acres breed recommendations in terms of energy, which may explain the differences in response, compared to other published trials.

Interestingly, despite the primary mode of action of lysolecithin on lipid emulsification, hydrolysis, and absorption, the improvements in performance in the current study came from the better utilization of diets containing no added fat or oil. Studies have shown that nutrient absorption enhancers can improve the digestion of non-fat nutrients (Zhang et al., 2011; Jansen et al., 2015; Haetinger et al., 2021), including amino acids (Wealleans et al., 2019). This will partially be driven by the dispersal of the fat matrix in the raw ingredients - the fat matrix often surrounds other nutrients and impedes access to digestive enzymes and processes. At the same time, the interaction of lysophospholipids with the gut wall causes them to be incorporated into the phospholipid bilayer of the cell walls, and lysophospholipids encourage transcellular nutrient transport through both passive and active mechanisms (Lundbaek and Andersen, 1994; Lundbaek, 2006). When present in the gut, lysophospholipids also alter host gene expression, increase the deposition of collagen (Brautigan et al., 2017), and enhances villus height and absorptive area (Papadopoulos et al., 2018; Boontiam et al., 2019).

These improvements in feed utilization efficiency for the chickens fed the lysolecithin-supplemented diets led to positive economic returns considering all costs and expenses, even if there is no indication of higher body weight in chickens receiving LEX supplemented diets in the current study. The net profit per chicken of the LEX regime is highly sensitive to changes in FCR and diet cost, as shown in Table 4. According to the results of the current study, profitability is heavily affected when the FCR difference decreases to 0.5 times or increases to 1.5 times. Moreover, with an increase in diet costs, the net benefit from improving diet efficiency also increases. Under commercial production circumstances, this can add up to substantial increases in profitability.

\section{CONCLUSION}

In conclusion, the inclusion of a nutrient absorption enhancer based on lysolecithin at $250 \mathrm{~g} / \mathrm{t}$ to low-energy diets allowed chickens to grow faster and more efficiently, than those fed non-supplemented diets, even in the absence of added oil to the diet formulation. Application of this nutrient absorption enhancer can lead to a significant positive net profit per chicken, especially when the price of the basal diet is high.

\section{DECLARATIONS}

\section{Acknowledgments}

The authors would like to express their appreciation to Cairo Poultry Group Management, Feed Division, Technical Office, R\&D team, and Kemin Animal Nutrition and Health team (a division of Kemin Europa N.V.) for their valuable support which made this research possible.

\section{Competing interests}

The authors declare that they have no competing interests.

\section{Authors' contribution}

All authors contributed equally to this work.

\section{Ethical considerations}

Ethical issues (including plagiarism, consent to publish, misconduct, data fabrication and/or falsification, double publication and/or submission, and redundancy) have been checked by the authors. 


\section{REFERENCES}

Boontiam W, Hyun YK, Jung B, and Kim YY (2019). Effects of lysophospholipid supplementation to reduced energy, crude protein, and amino acid diets on growth performance, nutrient digestibility, and blood profiles in broiler chickens. Poultry Science, 98(12): 6693-6701. DOI: https://www.doi.org/10.3382/ps/pex005.

Brautigan DL, Li R, Kubicka E, Turner SD, Garcia JS, Weintraut ML, and Wong EA (2017). Lysolecithin as feed additive enhances collagen expression and villus length in the jejunum of broiler chickens. Poultry Science, 96(8): 2889-2898. DOI: https://www.doi.org/10.3382/ps/pex078.

Chen C, Jung B, and Kim WK (2019). Effects of lysophospholipid on growth performance, carcass yield, intestinal development, and bone quality in broilers. Poultry Science, 98(9): 3902-3913. DOI: https://www.doi.org/10.3382/ps/pez111.

Haetinger VS, Dalmoro YK, Godoy GL, Lang MB, De Souza OF, Aristimunha P, and Stefanello C (2021). Optimizing cost, growth performance and nutrient absorption with a bio-emulsifier based on lysophospholipids for broiler chickens. Poultry Science, 100(4): $\begin{array}{llll}\text { Article } & \text { ID } & 101025 . & \text { DOI: }\end{array}$ https://www.doi.org/10.1016/j.psj.2021.101025.

Jansen M (2015). Modes of action of lysophospholipids as feed additives on fat digestion in broilers. Ph.D. Thesis, KU Leuven, Belgium. Available upon request at: https://limo.libis.be/primoexplore/fulldisplay?docid=LIRIAS1673616\&context=L\&vid=Liria s\&search scope=Lirias\&tab=default tab\&lang=en US\&fromSitem ap $=1$.

Jansen M, Nuyens F, Buyse J, Leleu S, and Van Campenhout L (2015). Interaction between fat type and lysolecithin supplementation in broiler feeds. Poultry Science, 94(10): 2506-2515. DOI: https://www.doi.org/10.3382/ps/pev181.

Johnson CA, Duong T, Latham RE, Shirley RB, and Lee JT (2020b). Effects of amino acid and energy density on growth performance and processing yield of mixed-sex Cobb $700 \times$ MV broiler chickens. Journal of Applied Poultry Research, 29(1): 269-283. DOI: https://www.doi.org/10.1016/j.japr.2019.10.014

Khonyoung D, amauchi KY, and Suzuki K (2015). Influence of dietary fat sources and lysolecithin on growth performance, visceral organ size, and histological intestinal alteration in broiler chickens. Livestock $\quad$ Science, 176 : 111-120. DOI: https://www.doi.org/10.1016/j.livsci.2015.03.011.

Lundbaek JA (2006). Regulation of membrane protein function by lipid bilayer elasticity: A single molecule technology to measure the bilayer properties experienced by an embedded protein. Journal of Physics Condensed Matter, 18: 1305-1344. Available at: https://iopscience.iop.org/article/10.1088/0953-8984/18/28/S13.

Lundbaek JA, and Andersen OM (1994). Lysophospholipids modulate channel function by altering the mechanical properties of lipid bilayers. The Journal of General Physiology, 104(4): 645-673. DOI: https://www.doi.org/10.1085/jgp.104.4.645.

Maiorka A, Da Silva AVF, Santin E, Pizauro JM, and Macari M (2004). Broiler breeder age and dietary energy level on performance and pancreas lipase and trypsin activities of 7-days old chicks. International Journal of Poultry Science, 3(3): 234-237. DOI: https://www.doi.org/10.3923/ijps.2004.234.237.

Maisonnier S, Gomez J, Brée A, Berri C, Baéza E, and Carré B (2003). Effects of microflora status, dietary bile salts and guar gum on lipid digestibility, intestinal bile salts, and histomorphology in broiler chickens. Poultry Science, 82(5): 805-814. DOI: https://www.doi.org/10.1093/ps/82.5.805.

Pan D, and Yu Z (2014). Intestinal microbiome of poultry and its interaction with host and diet. Gut Microbes, 5(1): 108-119. DOI: https://www.doi.org/10.4161/gmic.26945.

Papadopoulos GA, Poutahidis T, Chalvatzi S, Di Benedetto M, Hardas A, Tsiouris V, Georgopoulou I, Arsenos G, and Fortomaris PD (2018).
Effects of lysolecithin supplementation in low-energy diets on growth performance, nutrient digestibility, viscosity and intestinal morphology of broilers. British Poultry Science, 59(2): 232-239. DOI: https://www.doi.org/10.1080/00071668.2018.1423676.

Ravindran V, Tancharoenrat P, Zaefarian F, and Ravindran G (2016). Fats in poultry nutrition: Digestive physiology and factors influencing their utilisation. Animal Feed Science and Technology, 213: $1-21$.

DOI: https://www.doi.org/10.1016/j.anifeedsci.2016.01.012.

Sanz M, Flores A, and Lopez-Bote CJ (2000). The metabolic use of energy from dietary fat in broilers is affected by fatty acid saturation. British Poultry Science, 41(1): 61-68. Available at: https://www.tandfonline.com/doi/abs/10.1080/00071660086411?jo urnalCode $=\operatorname{cbps} 20$.

Smink W, Gerrits WJJ, Hovenier R, Geelen MJH, Lobee HWJ, Verstegen MWA and Beynen AC (2008). Fatty acid digestion and deposition in broiler chickens fed diets containing either native or randomized palm oil. Poultry Science, 87(3): 506-513.

Tancharoenrat P, Ravindran V, Zaefarian F, and Ravindran G (2013). Influence of age on the apparent metabolisable energy and total tract apparent fat digestibility of different fat sources for broiler chickens. Animal Feed Science and Technology, 186: 186-192. DOI: https://www.doi.org/10.1016/j.anifeedsci.2013.10.013.

Wealleans AL, Li W, Romero LF, Mathis G, and Lumpkins B (2018). Performance and cost-benefit improvements following supplementation with a combination of direct-fed microbials and enzymes to broiler chickens raised with or without ionophores. Journal of Applied Poultry Research, 27(1): 23-32. DOI: https://www.doi.org/10.3382/japr/pfx036.

Wealleans AL, Bindhu LV, Aka J, Kirwan S, and Ravindran V (2019). Influence of lysolecithin on the ileal digestibility of energy, fatty acids and amino acids in broilers. $15^{\text {th }}$ meeting Pig and Poultry Nutrition, 19-21. Halle, Germany. Available at: https://docplayer.org/175870475-Naturwissenschaftliche-fakultaetiii-institut-fuer-agrar-und-ernaehrungswissenschaften-15-tagungschweine-und-gefluegelernaehrung.html.

Wealleans AL, Buyse J, Scholey D, Van Campenhout L, Burton E, Pritchard S, Di Benedetto M, Nuyens F, and Jansen M (2020a). Lysolecithin but not lecithin improves nutrient digestibility and growth rates in young broilers. British Poultry Science, 61(4): 414423. DOI: https://www.doi.org/10.1080/00071668.2020.1736514.

Wealleans AL, Jansen M, and Di Benedetto M (2020b). Addition of lysolecithin to broiler diets improves growth performance across fat levels and sources. British Poultry Science, 61(1): 51-56. DOI: https://www.doi.org/10.1080/00071668.2019.1671955.

Wealleans AL, Bierinckx K, Witters E, di Benedetto M, and Wiseman J (2021). Assessment of the quality, oxidative status and dietary energy value of lipids used in non-ruminant animal nutrition. Journal of the Science of Food and Agriculture, pp. 1-12. DOI: https://www.doi.org/10.1002/jsfa.11066.

Wiseman J, Salvador F, and Craigon J (1991). Prediction of the apparent metabolizable energy content of fats fed to broiler chickens. Poultry Science, 70(7): 1527-1533. Available at: https://pubmed.ncbi.nlm.nih.gov/1886864/.

Zampiga M, Meluzzi A, and Sirri F (2016). Effect of dietary supplementation of lysophospholipids on productive performance, nutrient digestibility and carcass quality traits of broiler chickens. Italian Journal of Animal Science, 15(3): 521-528. DOI: https://www.doi.org/10.1080/1828051X.2016.1192965.

Zhang B, Haitao L, Zhao D, Guo Y, and Barri A (2011). Effect of fat type and lysophosphatidylcholine addition to broiler diets on performance, apparent digestibility of fatty acids, and apparent metabolizable energy content. Animal Feed Science and Technology, 163: 177-184. https://www.doi.org/10.1016/j.anifeedsci.2010.10.004. 